\title{
MEKANISME IMUNODEPRESI PASCASTROKE
}

\author{
POST-STROKE IMMUNODEPRESSION MECHANISMS
}

\author{
Al Rasyid*
}

\begin{abstract}
Immunodepression refers to a condition when immune system has reduced capacity to fulfill its functions therefore leading to infection. Infections develop frequently after stroke, and have been associated with poor clinical and functional outcome. Several studies show ischemic stroke, leads to impairment of immune responses, which increases susceptibility of an infection. This review analyzes the mechanisms of post-stroke immunodepression involving nervous system, such as adrenergic pathway, cholinergic pathway, or HPA axis, comprehensively based on recent clinical and experimental evidences. A better understanding of immune system modification after stroke could encourage further studies regarding immunomodulation therapy use in fighting infection.
\end{abstract}

Keywords: Immune response, infection, post-stroke immunodepression

\begin{abstract}
ABSTRAK
Imunodepresi merupakan suatu kondisi saat sistem imun tidak dapat menjalankan perannya dengan baik sehingga dapat menimbulkan suatu infeksi. Infeksi sendiri merupakan komplikasi yang umum terjadi pascastroke, dihubungkan dengan luaran klinis dan fungsional yang buruk pada pasien stroke. Berbagai studi klinis menyimpulkan kondisi iskemik pada stroke menyebabkan gangguan pada respons imun sehingga menimbulkan kerentanan terhadap infeksi. Tulisan ini membahas mekanisme imunodepresi pascastroke terkait sistem saraf, baik jalur adrenergik, kolinergik, dan aksis HPA, secara komprehensif berbasis bukti klinis maupun eksperimental. Pemahaman konsep modifikasi sistem imun pascastroke dapat mendorong studi-studi lanjutan terkait penggunaan terapi imunomodulasi untuk melawan komplikasi infeksi.
\end{abstract}

Kata kunci: Imunodepresi pascastroke, infeksi, respons imun

*Divisi Neurovaskular, Departemen Neurologi FK Universitas Indonesia/RSUPN Dr. Cipto Mangunkusumo

Korespondensi: alrasyid50@yahoo.com.

\section{PENDAHULUAN}

Hubungan antara komplikasi infeksi dengan stroke iskemik akut bersifat kompleks dan dua arah. Beberapa kasus infeksi dapat menyebabkan kejadian stroke iskemik akut dan komplikasi infeksi umumnya meningkat pascastroke. Infeksi dapat menyebabkan stroke melalui beberapa cara, misalnya via bakteremia sistemik, via endokarditis infektif, atau via vaskulitis infektif, contohnya pada neurosifilis. ${ }^{1}$ Sementara itu, stroke iskemik akut dapat menjadi faktor predisposisi terjadinya infeksi, contohnya risiko aspirasi yang meningkat pada kondisi imunodepresi terkait stroke/ stroke-induced immunodepression (SII).

Pascastroke dapat terjadi komplikasi seperti infeksi sekunder, epilepsi, sepsis. Komplikasi yang terjadi dibagi menjadi 3 fase, yaitu fase hiperakut, subakut, dan kronik. ${ }^{2}$ Infeksi pascastroke menjadi penyebab mortalitas hingga mencapai $20 \%$ dan morbiditas tertinggi. ${ }^{3}$ Rasio infeksi pascastroke bervariasi, mulai dari 5\% hingga 65\%, dengan kasus tersering berupa infeksi paru (pneumonia) dan infeksi saluran kemih (ISK). ${ }^{4}$ Beberapa faktor menjadi prediktor infeksi nosokomial ini, diantaranya diabetes melitus, disfagia, usia tua, riwayat penyakit paru obstruktif kronik (PPOK), penggunaan ventilasi mekanik, serta derajat stroke berat. ${ }^{5}$ Walau demikian, faktor-faktor tersebut sulit menjelaskan alasan tingginya insiden infeksi pascastroke. Pemahaman terhadap mekanisme perubahan imun pascastroke beserta konsekuensi klinisnya memberikan peluang bagi klinisi untuk meningkatkan imunitas dan mengurangi kejadian infeksi pascastroke.

\section{PEMBAHASAN}

\section{Komplikasi Infeksi Pascastroke}

Progresif stroke dibagi menjadi 3 fase, yaitu fase hiperakut, fase subakut, dan fase kronik. ${ }^{2}$ Pada fase akut, transformasi hemoragik merupakan komplikasi paling fatal, dengan insiden $8,5-30 \%$. Selanjutnya, pada fase subakut, timbul berbagai komplikasi berupa perdarahan gastrointestinal, peningkatan tekanan intrakranial, disfagia, kejang, dan infeksi. Sementara itu, komplikasi di fase kronik mencakup ulkus terkait tekanan (contoh ulkus dekubitus), nyeri, inkontinensia urin dan alvi, serta depresi. ${ }^{6}$ Berbagai 
studi di beberapa center menunjukkan kejadian komplikasi pascastroke bervariasi, yaitu 44\% sampai 95\%, termasuk pneumonia, infeksi saluran kemih (ISK), tromboemboli vena, nyeri sendi, sepsis, infark miokard akut, dan terjatuh. ${ }^{7-8}$ Studi Bovim dkk menunjukkan ada hubungan linier antara derajat stroke dengan terjadinya satu atau lebih komplikasi. ${ }^{8}$

Infeksi menjadi salah satu komplikasi paling umum yang dijumpai pada fase akut stroke. Metaanalisis Westendorp dkk menunjukkan angka infeksi pascastroke mencapai $30 \%$, dengan pneumonia dan ISK masing-masing menyumbang sepertiga angka ini. ${ }^{4}$ Angka serupa ditemukan pada studi kohort Boehme dkk dengan 24\% kasus infeksi sudah terjadi saat pasien datang. ${ }^{9}$ Pada studi ini, angka infeksi terutama pneumonia, meningkat seiring beratnya derajat stroke dan penurunan tingkat kesadaran. ${ }^{5}$ Luaran pascastroke juga dipengaruhi oleh kondisi infeksi. Pneumonia maupun ISK meningkatkan risiko luaran klinis yang buruk, seperti imobilisasi, kerentaan (frailty), dan rehabilitasi yang terlambat. ${ }^{4}$ Pneumonia sendiri berkaitan dengan kematian, dengan RO (rasio Odds) 3,62. ${ }^{4}$ Infeksi pascastroke iskemik yang terjadi selama perawatan meningkatkan risiko deteriorasi neurologis serta disabilitas bermakna. ${ }^{9}$ Infeksi juga dapat meningkatkan risiko stroke berulang. ${ }^{10}$

Walau beberapa faktor tertentu dapat memengaruhi terjadinya infeksi, contohnya disfagia, infark total pada sirkulasi anterior, dan usia tua, namun jejas pada sistem saraf pusat menjadi faktor independen yang menyebabkan individu menjadi sangat rentan terhadap infeksi. Rangkaian peristiwa ini dikenal dengan imunodepresi terkait stroke atau imunodepresi pascastroke. ${ }^{11}$ Infeksi sebagai manifestasi kondisi imunodepresi tergambarkan melalui insiden infeksi yang hampir sama pada pasien stroke, baik yang mendapat perawatan di bangsal umum, bangsal neurologi, unit perawatan intensif, maupun unit stroke, yang memiliki kelebihan dan kekurangan dalam perawatan pasien stroke. ${ }^{12}$

Melalui studi eksperimental, diketahui bahwa pasca-iskemia fokal otak, terjadi dualisme kerja sistem imun. Awalnya, terjadi proses inflamasi lokal sebagai bagian respons imun bawaan (innate).
Selanjutnya, terjadi rekrutmen sel inflamatori dan produksi mediator inflamasi sehingga merangsang aktivasi respons imun adaptif. Pada fase lanjutan, terjadi kondisi imunodepresi sistemik, ditandai dengan penurunan aktivitas sel $\mathrm{T}$ dan kadar sel $\mathrm{T}$ dan B dalam plasma. ${ }^{13}$

Proses inflamasi, pada kondisi ideal, bertujuan membuang debris dan sisa-sisa jaringan yang rusak dan mendorong perbaikan dan regenerasi jaringan. Namun beberapa studi menunjukkan bahwa inflamasi selama fase akut stroke dapat memperluas lesi stroke dan memperburuk defisit neurologis. ${ }^{14-15}$ Oleh karena itu, supresi imunitas sistemik dianggap sebagai mekanisme kompensasi terhadap kerusakan jaringan otak. ${ }^{10}$ Kondisi imunodepresi dapat mengurangi proses inflamasi hebat pada jaringan otak akibat iskemia, serta mencegah terjadinya reaksi autoimun yang dipicu neuroantigen. ${ }^{16}$ Respons antiinflamasi kompensatif ini memengaruhi sistem imun sistemik, baik imun bawaan maupun adaptif, serta respons lokal jaringan, seperti yang umum dijumpai pada sepsis atau trauma berat. Beberapa mediator antiinflamasi yang diketahui terlibat antara lain IL4, IL-10, dan transforming growth factor- $\beta$ (TGF- $\beta$ ). Walau banyak studi telah membuktikan fenomena ini, mekanisme terjadinya imunodepresi pascastroke belum dapat diketahui secara pasti.

\section{Hubungan Sistem Saraf Pusat dan Sistem Imun}

Hubungan sistem saraf pusat dan sistem imun berlangsung melalui 3 jalur utama: jaras humoral, jaras adrenergik, dan jaras kolinergik. ${ }^{12}$ Ketiga jalur ini dapat dipicu dengan 2 cara, yaitu melalui sistem saraf pusat itu sendiri atau melalui stimulasi vagus aferen. Sistem imun juga dapat dipicu oleh keberadaan sitokin proinflamasi sebagai bagian dari respons stres tubuh, baik bersifat lokal atau sistemik, yang mencapai sistem saraf pusat via aliran darah. Jejas otak iskemik, seperti stroke, dapat mengaktivasi jalur-jalur tersebut melalui berbagai mekanisme yang berbeda. ${ }^{17}$ Jalur-jalur tersebut mencakup mediatormediator yang memiliki reseptor yang melimpah di sel-sel imun, seperti norepinefrin, asetilkolin, dan hormone glukokortikoid. ${ }^{18}$ Hubungan sistem imun dan sistem saraf pusat disajikan pada Gambar 1, 
melibatkan ketiga jalur diatas. ${ }^{12}$

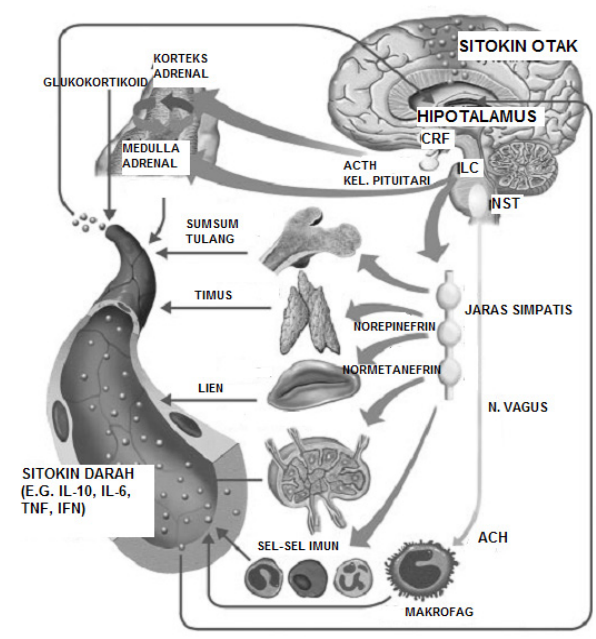

\section{Gambar 1. Mekanisme Komunikasi Sistem Saraf Pusat dan Sistem Imun ${ }^{12}$}

Aksis Hipothalamus-Pituitary-Adrenal (HPA) berperan penting dalam sistem neuroendokrin, dengan komponen utama terdiri atas nukleus paraventrikular, lobus anterior kelenjar hipofisis, dan lapisan korteks kelenjar adrenal. ${ }^{12}$ Hipotalamus akan menyekresikan corticotropin-releasing hormone (CRH) sebagai respons terhadap stresor, misalnya kondisi iskemia yang menyebabkan produksi sitokin proinflamasi seperti interleukin (IL)-1 $\beta$, tumor necrosis factor- $\alpha$ (TNF- $\alpha$ ), dan IL-6. Corticotropin-releasing hormone akan memicu sekresi adrenocorticotropin hormone (ACTH) dari kelenjar hipofisis anterior. ${ }^{19}$ Selanjutnya, ACTH dapat merangsang sekresi glukokortikoid dari zona fasikulata korteks adrenal, sehingga terjadi supresi produksi mediator proinflamasi, seperti IL-1 $\beta$, IL-11, IL-12, interferon- $\gamma$ (IFN- $\gamma$ ), TNF- $\alpha$, kemokin (IL-8), prostaglandin, dan nitric oxide (NO). Glukokortikoid juga merangsang sekresi mediator antiinflamasi, seperti IL-4, IL-10, dan TGF- $\beta$, serta memacu apoptosis sel-sel imun. ${ }^{20}$

Dalam sistem neuroendokrin, saraf simpatis memiliki peranan penting. Pada aktivasi saraf simpatis akibat stresor akut, terjadi sekresi katekolamin, termasuk epinefrin, norepinefrin, dan dopamin oleh ujung saraf (terminal nerve) dan medula adrenal. Dampaknya, terjadi efek simpatis berupa peningkatan denyut jantung, laju napas, tonus vaskular, serta perubahan imun. Perubahan terjadi akibat inhibisi aktivitas sel Th1 proinflamatori, menyebabkan dominasi aktivitas sel T-helper 2 (Th2) sebagai antiinflamasi, peningkatan apoptosis limfosit, dan disfungsi monosit. ${ }^{21-22}$ Salah satu sebabnya adalah organ-organ limfoid primer (contoh: timus dan sumsum tulang) dan sekunder (contoh: limpa dan nodus limfa) kaya akan inervasi saraf simpatis sehingga menjadi tempat sekresi katekolamin (epinefrin dan norepinefrin) dari terminal saraf. Hampir seluruh sel-sel imun, kecuali sel Th2, juga mampu mengekspresikan adrenoreceptor, termasuk limfosit, granulosit, makrofag, dan sel natural killer (NK) sehingga mempermudah transduksi sinyal ke dalam sel. ${ }^{17,23}$

Nukleus paraventrikularis memiliki fungsi yang berkaitan dengan pusat otonom, seperti nukleus traktus solitarius dan locus coeruleus. Melalui jaras ini, terjadi sinkronisasi respons neuroendokrin via jalur kolinergik yang bersifat antiinflamatori/ Cholinergic Anti-Inflammatory Pathway (CAP). Sitokin dan molekul pathogen-associated molecular pattern (PAMP) dapat mengaktivasi saraf vagus aferen. Selanjutnya, saraf vagus eferen (jalur kolinergik) menstimulasi sel $\mathrm{CD}^{+}$di lien, melalui sekresi norepinefrin oleh nervus splenikus adrenergik. Sel CD4 $4^{+}$melepaskan molekul asetilkolin, kemudian berikatan dengan reseptor nikotinik makrofag. Akibatnya, terjadi serangkaian signaling intraselular (contoh protein kinase A/PKA dan cyclic adenosine monophosphate/cAMP), mengakibatkan penurunan sitokin proinflamasi, seperti IL- $1 \beta$, TNF- $\alpha$, dan IL18 , dan aktivitas NF- $\kappa \beta .{ }^{24}$

Seperti yang telah disebutkan di atas, kelenjar adrenal berperan dalam regulasi sistem imun melalui aksis HPA. Namun, kelenjar adrenal juga dapat teraktivasi secara independen dari $\mathrm{ACTH}$ melalui neuron simpatis preganglionik yang mempersarafi sel-sel kromafin di medula adrenal, contohnya pada kondisi stres akut, seperti hipoglikemia, hipotensi hemoragik, asfiksia, dan distres. Akibatnya, kelenjar adrenal dapat menyekresikan katekolamin dalam sirkulasi sebagai suatu neurohormon, dengan rasio epinefrin dan norepinefrin sebesar 4:1. ${ }^{12}$ Senyawa ini selanjutnya dimetabolisme oleh catechol-O-methyltransferase (COMT), membentuk metanefrin dan 
normetanefrin. Regulasi sistem imun oleh sistem saraf juga terjadi pada organ limfoid. Katekolamin yang disekresikan di sel-sel imun pada organ limfoid meningkatkan cAMP dan merangsang PKA, sehingga terjadi inhibisi produksi TNF- $\alpha$, IL-1, IL12 , dan NO. ${ }^{12}$

Saat kondisi imunodepresi pascastroke, komunikasi sistem imun dan sistem saraf dapat terangkum pada Tabel $1 .{ }^{25}$ terhadap kondisi iskemia. Di jaringan otak, iskemia memicu respons inflamasi akibat nekrosis sel, dan produksi reactive oxygen species (ROS). Akibatnya, terjadi peningkatan sitokin dan kemokin dalam sirkulasi. Hal ini memicu mikroglia, sel imun pada otak, memproduksi sitokin proinflamasi dalam jumlah lebih banyak. Sementara itu, kemokin berfungsi merekrut sel-sel imun dalam sirkulasi ke area iskemik. ${ }^{27}$

Tabel 1. Mekanisme Interaksi Sistem Saraf Pusat dan Sistem Imun pada Kondisi Imunodepresii ${ }^{25}$

\begin{tabular}{|l|l|l|l|}
\hline \multicolumn{1}{|c|}{ VARIABEL } & $\begin{array}{l}\text { SISTEM SARAF PUSAT } \\
\text { (SSP) }\end{array}$ & \multicolumn{1}{|c|}{ JARAS HPA } & \multicolumn{1}{c|}{ N. VAGUS } \\
\hline TRIGGER & $\begin{array}{l}\text { Sitokin Inflamatorik via } \\
\text { Sirkulasi, N. Vagus Aferen }\end{array}$ & $\begin{array}{l}\text { Sitokin Inflamatorik via } \\
\text { Sirkulasi, N. Vagus Aferen }\end{array}$ & $\begin{array}{l}\text { Sitokin Inflamatorik via } \\
\text { Sirkulasi, N. Vagus Aferen }\end{array}$ \\
\hline SENSOR & $\begin{array}{l}\text { Area Kemoreseptif } \\
\text { Mesensefalon/ Midbrain }\end{array}$ & $\begin{array}{l}\text { Area Kemoreseptif } \\
\text { Mesensefalon/ Midbrain }\end{array}$ & $\begin{array}{l}\text { Area Kemoreseptif } \\
\text { Mesensefalon/ Midbrain }\end{array}$ \\
\hline MEDIATOR & $\begin{array}{l}\text { Traktus dan Serabut Saraf } \\
\text { Pusat }\end{array}$ & ACTH dalam Sirkulasi & N. Vagus Eferen \\
\hline EFEKTOR & Katekolamin & Limfosit, Makrofag, \\
TARGET (SISTEM IMUN) & Glukokortikoid & $\begin{array}{l}\text { Asetilkolin } \\
\text { Limfosit, Makrofag, }\end{array}$ & Makrofag Jaringan \\
\hline
\end{tabular}

\section{Respons Imun Bawaan dan Adaptif Pascastroke}

Iskemia serebral yang terjadi pada stroke menyebabkan kaskade perubahan sistem imun yang kompleks. Pada pascastroke, ditemukan peningkatan produksi sitokin dan infiltrasi sel inflamasi ke dalam sel-sel otak yamg iskemik. ${ }^{26}$ Namun, di saat yang bersamaan, terjadi aktivasi sistem saraf simpatis yang menyebabkan kondisi imunodepresi.

Saat aliran darah serebral terhenti, terjadi stres selular sehingga sinyal danger associated molecular patterns (DAMPs), contohnya protein High Mobility Group B1 (HMGB1), disekresi oleh sel-sel yang telah mati. Sinyal ini kemudian dikenali oleh efektor respons imun bawaan (innate), dengan mekanisme yang tidak jauh berbeda dengan interaksi pathogen associated molecular patterns (PAMPs) di permukaan bakteri gram negatif dengan Toll-like receptor (TLR). ${ }^{26}$ Danger associated molecular patterns juga dapat berinteraksi dengan antigen presenting cell (APC), seperti sel dendritik, sehingga respons imun adaptif ikut teraktivasi. ${ }^{26}$

Sejumlah sitokin turut diekspresikan secara sentral maupun perifer, sebagai bagian dari respons
Sitokin-sitokin ini, seperti IL-1, IL-6, dan TNF- $\alpha$ mampu meningkatkan ekspresi molekul adhesi (adhesion molecule) leukosit pada endotel vaskular. Molekul adhesi, seperti integrin dan selektin, dapat mempermudah infiltrasi leukosit ke dalam jaringan parenkim otak. Pada jaringan otak, leukosit serta mikroglia memproduksi mediator proinflamatori, seperti matrix metalloproteinase (MMP), inducible nitric oxide synthase (iNOS), sitokin, dan ROS. Selain itu, leukocyte adherence oleh aktivitas molekul adhesi pun dapat terjadi, menimbulkan no-flow phenomenon. Aktivitas inflamasi dalam parenkim otak maupun no-flow phenomenon menyebabkan jejas berupa edema otak, perdarahan, dan kematian sel dalam 24 jam pertama pascaawitan stroke. ${ }^{27}$ Selain itu, sitokin-sitokin proinflamasi, akumulasi ROS akibat oklusi arteri, dan downregulation protein taut endotel (endothelial junction) menimbulkan efek kumulatif berupa penurunan integritas sawar darah otak (blood-brain barrier) ${ }^{28}$

Respons imun adaptif teraktivasi mulai 24 jam pascastroke. ${ }^{29}$ Sel NK dan sel $\mathrm{T} \mathrm{CD} 4^{+}$memperberat 
toksisitas neuronal melalui sekresi sitokin seperti IL-17 dan IFN- $\gamma .{ }^{30}$ Proses ini berlangsung tanpa keterlibatan antigen. Sel $\mathrm{T}$ yang bersifat spesifik terhadap suatu antigen baru akan bekerja kemudian saat terjadi reaksi autoimun dan immunotolerance. Sementara itu, peran sel B dalam produksi antibodi terhadap molekul turunan otak (brain-derived molecules) mengakibatkan kerusakan neuronal berminggu-minggu pascaawitan stroke. ${ }^{31}$ Respons inflamasi awal ini bersifat swasirna (self-limiting) dan bertujuan untuk rekonstruksi struktural jaringan otak. Fase inflamasi stroke diakhiri oleh 3 proses, yaitu pembuangan sel mati dan debris, produksi faktor prosurvival untuk regenerasi neuron, dan pembentukan respons antiinflamasi. ${ }^{32}$ Proses terakhir ini diduga berperan pada imunodepresi pascastroke, ditandai dengan limfopenia, atrofi lien, dan peningkatan kadar sitokin antiinflamasi.

\section{Mekanisme Imunodepresi: Peranan Sistem Neuroendokrin dan Saraf Otonom}

Hubungan sistem saraf pusat dan sistem imun berlangsung secara dua arah. Pada tahap awal pasca-iskemia otak, terjadi respons inflamasi sistemik yang diperantarai oleh organ limfoid primer dan sekunder. Dalam 24 jam pertama, ditemukan peningkatan kadar sitokin, kemokin, dan berbagai mediator proinflamasi dalam sirkulasi. Selanjutnya, terjadi kejadian lanjutan berupa imunodepresi, atau dikenal dengan istilah imunodepresi pascastroke. ${ }^{33}$ Sistem saraf pusat membentuk kondisi ini melalui serangkaian jaras neural dan humoral yang kompleks, melibatkan sistem saraf simpatis, nervus vagus, dan aksis HPA. Walau secara teoretis komplikasi pascastroke mungkin terjadi, namun di sisi lain respons imunodepresi dapat melindungi saraf pusat dari reaksi autoimun berlebihan. Pada tahap akut stroke, kerusakan integritas sawar darah otak memungkinkan interaksi antara antigen yang tersekuestrasi di otak dengan sel-sel imun untuk kali pertama. ${ }^{28}$ Antigen-antigen selanjutnya dapat memasuki sirkulasi sistemik, dan memicu sel T dan sel B autoreaktif pada nodus limfa. ${ }^{34}$

Regulasi imunitas pascastroke berlangsung melalui kontrol kompleks yang melibatkan sistem imun, sistem saraf, dan sistem endokrin. Dengan demikian, terdapat 2 jalur yang mengatur fungsi imun, yaitu jalur neural dan jalur humoral. Jalur neural mengaktivasi maupun menginhibisi fungsi imun melalui persarafan, terutama saraf simpatis, di organ-organ imun primer dan sekunder. Sistem saraf simpatis mengalami peningkatan aktivitas selama stroke, dan memicu kondisi imunodepresi melalui 2 jalur, yaitu jalur $\beta$-arrestin-2-NF- $\kappa \beta$ dan jalur cAMPPKA-NF- $\kappa \beta .{ }^{35-36}$ Ketika terjadi aktivasi saraf simpatis, efektor utama berupa katekolamin (contoh epinefrin, norepinefrin, dan dopamin) akan dilepas ke sirkulasi. Apabila terjadi peningkatan kadar katekolamin berkepanjangan, maka jumlah limfosit yang beredar akan tereduksi. ${ }^{6}$ Stroke juga memicu kondisi hiperglikemia terkait resistensi insulin, dimana

\section{SIKLUS PERUBAHAN SISTEM IMUN PASCA STROKE}

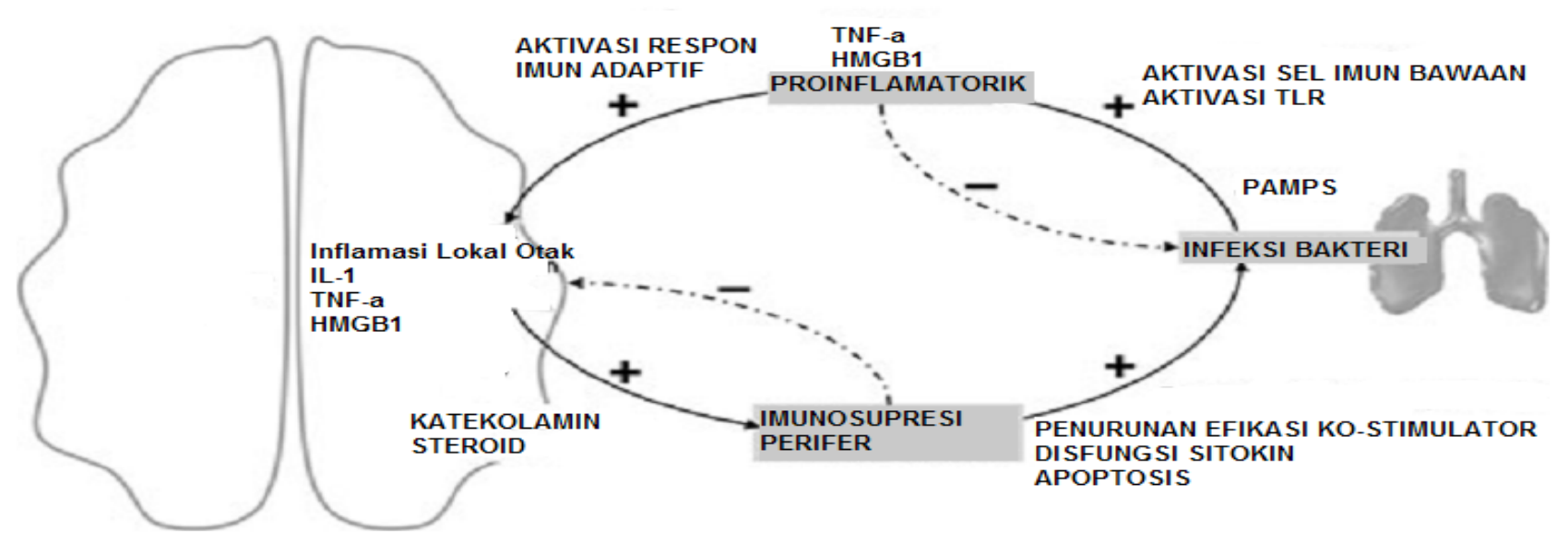

Gambar 2. Perubahan Sistem Imun Pascastroke ${ }^{29}$ 
berhubungan dengan peningkatan kadar katekolamin berlebihan. Sementara itu, jalur kolinergik (saraf parasimpatis) antiinflamatori meliputi nervus vagus, lien, dan reseptor $\alpha-7$ asetilkolin nikotinik (nAChR). ${ }^{37}$ Asetilkolin, neurotransmiter utama jalur kolinergik, mampu menghambat pelepasan sitokin proinflamasi perifer. Berdasarkan studi Engel dkk jalur kolinergik ini berhubungan dengan mekanisme imun neural dan memegang peranan penting dalam patogenesis pneumonia terkait stroke. ${ }^{38}$

Jalur humoral berkaitan dengan perubahan kadar neurotransmiter, neuropeptida, hormon, dan senyawa kimia lainnya. Nukleus paraventrikularis di hipotalamus distimulasi oleh berbagai sitokin di fase akut stroke untuk menyintesis corticotropinreleasing factor (CRF), selanjutnya memulai aktivitas aksis HPA. ${ }^{12}$ Dampaknya, terjadi sekresi masif glukokortikoid (kortisol) dari zona fasikulata kelenjar adrenal, sehingga terjadi limfositopenia dan perubahan keseimbangan jumlah mediator inflamasi dan antiinflamasi. ${ }^{39}$ Walau kortisol telah lama diketahui memiliki efek imunosupresan, nyatanya menurut studi Mracsko dkk, peran saraf simpatis lebih besar pada fenomena imunodepresi pascastroke. ${ }^{39}$ Kerja kedua jalur tersebut tersinkronisasi melalui nukleus paraventrikularis, membentuk kondisi imunodepresi terjadi 24 jam pascaawitan stroke dan bertahan hingga berminggu-minggu. ${ }^{40-41}$ Dalam Gambar 2, terlihat perubahan sistem imun pascastroke, dimana terjadi sekresi sitokin proinflamatori sekaligus penekanan respons imun perifer, diperantarai oleh aktivasi sistem saraf simpatis (katekolamin) dan aksis HPA (steroid). ${ }^{29}$

\section{Imunodepresi Pascastroke: Studi Klinis dan Eksperimental}

Imunodepresi pascastroke diketahui sebagai representasi adaptasi sistem saraf pusat untuk membatasi area inflamasi akibat iskemia. Secara sederhana, overaktivasi sistem saraf otonom dan sekresi hormon stres menyebabkan perubahan respons imun bawaan dan adaptif. Berbagai studi klinis dan eksperimental telah banyak dilakukan untuk membuktikan hipotesis tersebut.

Menurut laporan beberapa studi, stroke mengganggu fungsi sistem imun, termasuk kemampuan bakterisidal. Akibatnya, pasien yang mengalami stroke, rentan terhadap infeksi. Pascastroke, ekspresi MHC kelas II (HLA-DR) menurun, ko-stimulasi respons imun spesifik menjadi kurang efisien, dan produksi sitokin proinflamasi oleh makrofag turut berkurang. ${ }^{42-44}$ Monocytic HLA$D R$ (mHLA-DR) sendiri diketahui sebagai biomarker imunodepresi. Indikator lain kondisi imunodepresi adalah organ imun yang mengalami atrofi, terutama lien dan timus. ${ }^{45}$ Apoptosis splenosit menyebabkan penurunan produksi faktor mitogenik sel T, sehingga proliferasi sel $\mathrm{T}$, termasuk produksi sitokin inflamasi, terhambat. Pada sel T sendiri, terjadi pergeseran (shift), dimana sel T helper 1 (Th1) pro-inflamatori menjadi kurang aktif, berganti menjadi sel Th2 yang bersifat antiinflamatori. Hal ini bertujuan untuk melindungi jaringan otak dari kerusakan akibat inflamasi lebih lanjut dan mendorong regenerasi neuronal. Namun di sisi lain, kemampuan imunitas sistemik menghadapi patogen melemah sehingga rentan terhadap infeksi. ${ }^{46}$ Sekresi IL-10 oleh monosit, sel dendritik, dan sel $\mathrm{T}$ regulator mengalami peningkatan sebagai bagian mekanisme neuroprotektif. Sitokin antiinflamasi ini mendorong perubahan respons imun Th1 menjadi Th2. Selain itu, IL-10 dapat menghambat produksi IFN- $\gamma$ oleh sel Th1, proliferasi sel T, produksi TNF- $\alpha$ oleh makrofag, dan berbagai sitokin porinflamasi lain. ${ }^{47}$ Studi eksperimental pada tikus melaporkan adanya penurunan kadar serum IFN- $\gamma$ dan TNF- $\alpha$ pada 12 jam pascaawitan stroke. ${ }^{45}$

Peningkatan produksi IL-10, serta reduksi TNF- $\alpha$, diperantarai oleh senyawa katekolamin yang bekerja melalui reseptor $\beta$-adrenergik pada sel-sel imun. ${ }^{48}$ Glukokortikoid yang disekresikan oleh medula adrenal juga bekerja pada sel $\mathrm{T}$, untuk menghambat produksi IFN- $\gamma$, serta pada monosit, untuk meningkatkan sekresi IL-10. Katekolamin dan glukortikoid yang disekresikan pascastroke pun menyebabkan kondisi limfopenia. ${ }^{45}$

Studi Mracsko dkk, menyimpulkan bahwa kadar hormon stres hanya akan meningkat pada infark hemisfer ekstensif. ${ }^{39}$ Temuan ini sesuai dengan observasi yang dilakukan studi Liesz 
dkk. ${ }^{49}$ Hanya infark ekstensif yang menghasilkan penurunan volume lien dan jumlah splenosit. Selain itu, kondisi limfositopenia berhubungan dengan peningkatan kadar glukokortikoid dalam plasma. Apoptosis limfosit terkait prednisolon didominasi oleh limfosit, dibandingkan monosit atau granulosit, serta diperantarai oleh reseptor glukokortikoid. Dengan demikian, blokade reseptor glukokortikoid dapat mencegah apoptosis limfosit lien dan menstabilkan kadar sel T dalam plasma. Studi ini juga menyimpulkan bahwa sekresi IFN- $\gamma$, sitokin utama pada infeksi bakteri pascastroke, oleh limfosit dapat dihambat akibat peningkatan kadar katekolamin via adrenoreseptor $\beta 2 .{ }^{39}$ Sementara itu, studi Yan $\mathrm{dkk}$, menyimpulkan oklusi arteri serebri media menyebabkan overaktivasi sistem saraf simpatis, ditandai dengan peningkatan kadar metanefrin (MN) dan normetanefrin (NMN), yang terlihat jelas 72 jam pasca-iskemia. Kadar MN dan NMN dalam plasma memiliki asosiasi signifikan dengan perubahan volume lien. Melalui pemberian propanolol, antagonis adrenoreseptor $\beta$, sebelum dan sesudah terjadinya iskemia, timbul reversibilitas volume lien dan imunodepresi sistemik secara signifikan. Melalui eksperimen ini, dapat disimpulkan, overaktivasi sistem saraf simpatis memicu apoptosis limfosit perifer, terutama pada lien, dan mengakibatkan kondisi imunodepresi. ${ }^{50}$

\section{Imunodepresi Pascastroke di Masa Depan}

Imunodepresi akibat stres akut pascastroke merupakan tantangan besar dalam tata laksana pasien stroke. Seperti yang telah dibahas sebelumnya, fenomena imunodepresi di tingkat klinis masih menimbulkan banyak tanda tanya. Misalnya, apakah imunodepresi pascastroke benar dapat meningkatkan risiko infeksi pada pasien? Atau, infeksi berperan dalam perburukan klinis pascastroke?

Walau masih bersifat abu-abu, beberapa studi eksperimental berusaha membuat suatu strategi terapi yang menargetkan imunodepresi pascastroke atau setidaknya mengurangi disfungsi imun pascastroke. Misalnya, penggunaan inhibitor kaspase untuk mereduksi apoptotic brain damage dan apoptosis limfosit. Melalui percobaan pada tikus dengan MCAO (middle cerebral artery occlusion), inhibitor ini dapat mengurangi kerentanan terhadap bakteremia dan meningkatkan survival. ${ }^{51}$ Pada studi eksperimental lain, terapi pada tikus MCAO dengan recombinant $T$ lymphocyte receptor ligands (RTL), suatu molekul major histocompability complex (MHC) kelas II, mampu mereduksi ukuran lesi infark stroke, sekaligus memperbaiki perbaikan luaran neurokognitif jangka panjang. ${ }^{52}$ Terapi ini memberikan peluang perbaikan luaran stroke tanpa harus mengurangi fungsi sistem imun. Namun, pada studi lain, reduksi respons inflamasi terbukti bermanfaat dalam mencegah perluasan jejas iskemik pascastroke. ${ }^{43}$ Secara teoretis, mereduksi respons inflamasi secara tidak langsung mereduksi kerusakan jaringan sekaligus mereduksi respons imun protektif pascastroke. Sementara itu, terapi antibiotik profilaksis untuk mencegah infeksi pascastroke belum menghasilkan kesimpulan yang seragam. Hal ini dapat dipahami mengingat antibiotik tidak bekerja pada mekanisme yang mendasari imunodepresi. ${ }^{26}$

Studi lebih lanjut dibutuhkan untuk memahami respons imun pascastroke lebih mendalam, terutama pada aspek keterkaitan antara kondisi imunodepresi dan insiden infeksi. Lebih jauh, minimalisasi jejas otak tanpa menurunkan fungsi sistem imun dapat menjadi landasan tata laksana stroke komprehensif di masa depan.

\section{KESIMPULAN}

Kondisi imunodepresi pascastroke merupakan komplikasi yang terjadi akibat adanya stresor pada sistem saraf akibat kondisi iskemik. Studi lebih lanjut diperlukan untuk memahami hubungan kausalitas antara kondisi imunodepresi dan infeksi pascastroke, serta regimen terapi modifikasi imun yang tepat dalam tata laksana infeksi pascastroke.

\section{DAFTAR PUSTAKA}

1. Fugate JE, Lyons JL, Thakur KT, Smith BR, HedleyWhyte ET, Mateen FJ. Infectious causes of stroke. Lancet Infect Dis. 2014;14:869-80.

2. Bustamante A, Garcia-Berrocoso T, Rodriguez N, Llombart V, Ribo M, Molina C, dkk. Ischemic stroke outcome: a review of the influence of post stroke complications within the different scenarios of stroke care. Eur J Intern Med. 2016;29:9e21. 
3. Shi K, Wood K, Shi FD, Wang X, Liu Q. Strokeinduced immunosuppression and poststroke infection. Stroke Vasc Neurol. 2018;3:e000123.

4. Westendorp WF, Nederkoorn PJ, Vermeij JD, Dijkgraaf MG, Van-De-Beek D. Post-stroke infection: a systematic review and meta-analysis. BMC Neurol. 2011;11:110.

5. Wastfelt M, Cao Y, Strom JO. Predictors of poststroke fever and infections: a systematic review and meta-analysis. BMC Neurology. 2018;18:49.

6. Liu DD, Chu SF, Chen C, Yang PF, Chen NH, $\mathrm{He} \mathrm{X}$. Research progress in stroke-induced immunodepression syndrome (SIDS) and strokeassociated pneumonia (SAP). Neurochem Int. 2018;114:42-54.

7. Civelek GM, Atalay A, Turhan N. Medical complications experienced by first-time ischemic stroke patients during inpatient, tertiary level stroke rehabilitation. J Phys Ther Sci. 2016;28:382-91.

8. Bovim MR, Askim T, Lydersen S, Fjaertoft $H$, Indredavik B. Complications in the first week after stroke: a 10-year comparison. BMC Neurol. 2016;16:133.

9. Boehme AK, Kumar AD, Dorsey AM, Siegler JE, Aswani MS, Lyerly MJ, dkk. Infections presents on admission compared with hospital-acquired infections in acute ischemic stroke patients. J Stroke Cerebrovasc. 2013;22(8):e582-9.

10. Shim R, Wong CHY. Ischemia, immunosuppression, and infection-tackling the predicaments of poststroke complications. Int J Mol Sci. 2016;17(1):64.

11. Urra X, Obach V, Chamorro A. Stroke induced immunodepression syndrome: from bench to bedside. Curr Mol Med. 2009;9(2):195-202.

12. Chamorro A, Urra X, Planas AM. Infection after acute ischemic stroke: a manifestation of brain induced immunodepression. Stroke. 2007;38:1097-103.

13. Folyovich A, Biro E, Orban C, Bajnok A, Varga V, Molnar AKB, dkk. Relevance of novel inflammatory markers in stroke-induced immunosuppression. BMC Neurology. 2014; 14:41.

14. Fu Y, Liu Q, Anrather J, Shi FD. Immune interventions in stroke. Nat Rev Neurol. 2015;11:524-35.

15. Urday S, Kimberly WT, Beslow LA, Vortmeyer AO, Selim MH, Rosand J, dkk. Targeting secondary injury in intracerebral haemorrhage-perihaematomal oedema. Nat Rev Neurol. 2015;11:111-22.

16. Römer $\mathrm{C}$, Engel $\mathrm{O}$, Winek $\mathrm{K}$, Hochmeister $\mathrm{S}$, Zhang T, Royl G, dkk. Blocking stroke-induced immunodefiiency increases CNS antigen-specifi autoreactivity but does not worsen functional outcome after experimental stroke. J Neurosci. 2015;35:7777-
94.

17. Schulze J, Vogelsang A, Dressel A. Catecholamines, steroids and immune alterations in ischemic stroke and other acute diseases. Aging Dis. 2014;5(5):32739.

18. Liu Q, Jin WN, Liu Y, Shi K, Sun H, Zhang F, dkk. Brain ischemia suppresses immunity in the periphery and brain via different neurogenic innervations. Immunity. 2017;46:474-87.

19. Nezi M, Mastorakos G, Mouslech Z. Corticotropin releasing hormone and the immune/ inflammatory response. South Dartmouth [serial online]. 2000 [diunduh 30 Juli 2015]. Tersedia dari: NIH.

20. Bereshchenko O, Bruscoli S, Riccardi C. Glucocorticoids, sex hormones, and immunity. Front Immunol. 2018;9:1332.

21. Winklewski PJ, Radkowski M, Demkow U. Crosstalk between the inflammatory response, sympathetic activation, and pulmonary infection in the ischemic stroke. J Neuroinflamm. 2014;11:213.

22. Walter U, Kolbaske S, Patejdl R, Steinhagen V, AbuMugheisib M, Grossmann A, dkk. Insular stroke is associated with acute sympathetic hyperactivation and immunodepression. Eur J Neurol. 2013;20:1539.

23. Scanzano A, Cosentino M. Adrenergic regulation of innate immunity: a review. Front Immunol. 2015;6:171.

24. Pavlov VA, Chavan SS, Tracey KJ. Molecular and functional neuroscience in immunity. Annu Rev Immunol. 2018;36:783-812.

25. Meisel C, Schwab JM, Prasss K, Meisel A, Dirnagl U. Central nervous system injury-induced immune deficiency syndrome. Nature. 2005;6:775-86.

26. Famakin BM. The immune response to acute focal cerebral ischemia and associated post-stroke immunodepression: a focused review. Aging Dis. 2014;5(5):307-26.

27. Kawabori M, Yenari MA. Inflammatory responses in brain ischemia. Curr Med Chem. 2015;22(10):125877.

28. Malone K, Amu S, Moore AC, Waeber C. The immune system and stroke: from current targets to future therapy. Immunol Cell Biol. 2019;97(1):5-16.

29. Vogelgesang A, Becker KJ, Dressel A. Immunological consequences of ischemic stroke. Acta Neurol Scand. 2014;129(1):1-12.

30. Petrovic-Djergovic D, Goonewardena SN, Pinsky DJ. Inflammatory disequilibrium in Stroke. Circ Res. 2016;119(1):142-58.

31. Selvaraj UM, Poinsatte K, Torres V, Ortega SB, Stowe AM. Heterogeneity of B cell functions in 
stroke-related risk, prevention, injury, and repair. Neurotherapeutics. 2016;13(4):729-47.

32. Shichita T, Ito M, Yoshimura A. Post-ischemic inflammation regulates neural damage and protection. Front Cell Neurosci. 2014;8:319.

33. Brambilla R, Couch Y, Lambertsen KL. The effect of stroke on immune function. Mol Cell Neurosci. 2013;53:26-33.

34. Planas AM, Gomez-Choco M, Urra X, Gorina R, Caballero M, Chamorro A. Brain-derived antigens in lymphoid tissue of patients with acute stroke. J Immunol. 2012;188:2156-63.

35. Deng QW, Yang H, Yan FL, Wang H, Xing FL, Zuo L, dkk. Blocking sympathetic nervous system reverses partially stroke-induced immunosuppression but does not aggravate functional outcome after experimental stroke in rats. Neurochem Res. 2016;41:1877-86.

36. Zuo L, Shi L, Yan F. The reciprocal interaction of sympathetic nervous system and cAMP-PKA-NF-kB pathway in immune suppression after experimental stroke. Neurosci Lett. 2016;627:205-10.

37. Martelli D, McKinley MJ, McAllen RM. The cholinergic anti-inflammatory pathway: a critical review. Auton. Neurosci. 2014;182:65-9.

38. Engel O, Akyuz L, Da-Costa-Goncalves AC, Winek K, Dames C, Thielke M, dkk. Cholinergic pathway suppresses pulmonary innate immunity facilitating pneumonia after stroke. Stroke. 2015;46:3232-40.

39. Mracsko E, Liesz A, Karcher S, Zorn M, Bari F, Veltkamp R. Differential effects of sympathetic nervous system and hypothalamicepituitaryeadrenal axis on systemic immune cells after severe experimental stroke. Brain Behav Immun. 2014;41:200-9.

40. El Husseini N, Laskowitz DT. The role of neuroendocrine pathways in prognosis after stroke. Expert Rev Neurother. 2014;14:217-32.

41. Harms H, Grittner U, Droge H, Meisel A. Predicting post-stroke pneumonia: the pantheris score. Acta Neurol Scand. 2013;128:178-84.

42. Meisel A, Meisel, C, Harms H, Hartmann O, Ulm L. Predicting post-stroke infections and outcome with blood-based immune and stress markers. Cerebrovasc Dis. 2012;33:580-8.
43. Vogelgesang A, Grunwald U, Langner S, Jack R, Broker BM, Kessler C, dkk. Analysis of lymphocyte subsets in patients with stroke and their influence on infection after stroke. Stroke. 2008;39:237-41.

44. Hug A, Liesz A, Muerle B, Zhou W, Ehrenheim J, Lorenz A, dkk. Reduced efficacy of circulating costimulatory cells after focal cerebral ischemia. Stroke. 2011;42:3580-6.

45. Prass K, Meisel C, Hoflich C, Braun J, Halle E, Wolf $\mathrm{T}$, dkk. Stroke-induced immunodeficiency promotes spontaneous bacterial infections and is mediated by sympathetic activation reversal by poststroke $\mathrm{T}$ helper cell type 1-like immunostimulation. J Exp Med. 2003;198:725-36.

46. Chamorro A, Horcajada J, Obach V, Vargas M, Revilla $\mathrm{M}$, Torres F, dkk The early systemic prophylaxis of infection after stroke study a randomized clinical trial. Stroke. 2005;36:1495-500.

47. Chamorro A, Amaro S, Vargas M, Obach V, Cervera $\mathrm{A}$, Torres $\mathrm{F}$, dkk. Interleukin 10, monocytes and increased risk of early infection in ischaemic stroke. J Neurol Neurosurg. Psychiatry. 2006;77:1279-81.

48. Sillas AA, Luquin DDA, Dominguez BT, Fuentes SG, Garcia AT, Salas MM, dkk. Regulatory T cells: molecular actions on effector cells in immune regulation. J Immunol Res. 2016;2016:1720827.

49. Liesz A, Ruger H, Purrucker J, Zorn M, Dalpke A, Mohlenbruch M, dkk. Stress mediators and immune dysfunction in 653 patients with acute cerebrovascular diseases. PLoS ONE. 2013;8(9):e74839.

50. Yan FL, Zhang JH. Role of the sympathetic nervous system and spleen in experimental stroke-induced immunodepression. Med Sci Monit. 2014;20:248996.

51. Urra X, Cervera A, Obach V, Climent N, Planas AM, Chamorro A. Monocytes are major players in the prognosis and risk of infection after acute stroke. Stroke. 2009;40(4):1262-8.

52. Zhu W, Casper A, Libal NL, Murphy SJ, Bodhankar S, Offner H, dkk. Preclinical evaluation of recombinant T-cell receptor ligand RTL1000 as a therapeutic agent in ischemic stroke. Transl Stroke Res. 2015;6(1):608. 